\title{
Towards Legal Coherence in Trademark Law and Investment Law of Asean Countries Post AEC (Asean Economic Community) Blueprint $\mathbf{2 0 2 5}^{1}$
}

\author{
Tomi Suryo Utomo \\ Faculty of Law University of Janabadra \\ Jln. Timoho II/40 Yogyakarta \\ utomo.ts@gmail.com
}

Received: 10 Nopember 2017; Accepted: 16 Maret 2018; Published: 14 Agustus 2018

DOI: 10.20885/iustum.vol25.iss1.art3

\begin{abstract}
The blueprint of the ASEAN Economic Community (AEC) 2025 is adopted by ASEAN members on November 22 , 2015. To discuss this issue, this paper focused on analyzing any challenges in achieving legal coherence in terms of brand and trade among the ASEAN countries and analyzing the principles and strategies to create legal coherence in terms of brand and investment laws in ASEAN countries. This was a normative research using statute approach and law comparison that analyzed secondary data qualitatively. This paper concluded that legal coherence in brand and investment laws can be achieved if ASEAN could overcome various challenges such as differences in legal, economic and technological systems, legal culture and infrastructure development. The principles required are the harmonization of laws and policies to abolish trade barriers related to borders. Some of the strategies of legal coherence are to make Blueprint as a guideline and to apply harmonization of law through standardization and technical regulation reformation.
\end{abstract}

Keywords: AEC blueprint 2025; business law; investment law; legal coherence; ASEAN economic community (AEC)

\section{Abstrak}

Cetak Biru Masyarakat Ekonomi ASEAN (MEA) 2025 diadopsi oleh anggota ASEAN pada 22 November 2015. Untuk membahas masalah tersebut, paper ini difokuskan untuk mengkaji tantangan dalam mencapai koherensi hukum di bidang merek dan dagang di negara-negara ASEAN serta menganalisis prinsip dan strategi dalam menciptakan koherensi hukum di bidang hukum merek dan investasi di negara-negara ASEAN. Jenis penelitian ini adalah normatif melalui pendekatan perundang-undangan dan perbandingan hukum yang menganalisa data sekunder secara kualitatif. Paper ini menyimpulkan bahwa koherensi hukum di bidang hukum merek dan investasi dapat dicapai jika ASEAN dapat mengatasi tantangan seperti perbedaan sistem hukum, ekonomi dan teknologi, budaya hukum serta pembangunan infrastruktur. Prinsip yang diperlukan adalah harmonisasi hukum dan kebijakan meniadakan hambatan perdagangan terkait perbatasan. Strategi koherensi hukum, diantaranya adalah menjadikan Blueprint sebagai pedoman dan menerapkan harmonisasi hukum melalui standardisasi dan reformasi peraturan yang bersifat teknis.

Kata-kata Kunci: Cetak Biru MEA 2025; Hukum Bisnis; Hukum Investasi; Koherensi Hukum; Masyarakat Ekonomi ASEAN (MEA)

${ }^{1}$ A large portion of this paper has been presented in the seminar 'Developing a Regulatory System that is Coherent Among ASEAN Countries to Support the ASEAN Economic Community', held by the Ministry of Law and Human Rights, Republic of Indonesia on 5 August 2015 in Jakarta. Considering that there are many recent developments regarding the implementation of AEC, the writer has made numerous substantive changes to this paper. 


\section{Introduction}

The ASEAN Economic Community ('AEC') is one of the most important events in the history of the ASEAN countries ${ }^{2}$. As one of the core pillars of ASEAN, the AEC was successfully established in 2016 as a continuation of the declaration made by the ASEAN leaders in the 9 ${ }^{\text {th }}$ ASEAN Summit ('Bali Concord II') to create a regional economic integration that will further strengthen the economic development of the ASEAN countries. ${ }^{3}$

In contrast to the European Union ('EU') whose political integration is already quite mature ${ }^{4}$ ASEAN's economic integration through the AEC is still in its infancy. In this phase, the economic integration is primarily focused on the removal of all substantial trade barriers between the different ASEAN Member States, namely: a) tariffs (i.e. taxes levied on the imported goods/services of other States); b) quotas (limitations on the amount of imported goods/services) and c) border restrictions ${ }^{5}$

As stipulated in the 2008-2015 Blueprint, the AEC's primary goals to reach before 2016 are: a) a single market and production basis; b) a competitive economic region; c) economic development for its Member States; d) a region that is full integrated with the global economy. 6 Fast forward one year after the AEC's establishment, the ASEAN Member States developed a new Blueprint entitle The

${ }^{2}$ The 8 August 1967 is a historic moment for the citizens of South East Asia, because it was at that moment that the Association of Southeast Asian Nations ('ASEAN') was formed by five founding members, namely Indonesia, Thailand, Filipina, Malaysia and Singapore. 10 years since its inception, its members subsequently agreed to form a regional economic area that is called the ASEAN Economic Community ('AEC') at the end of 2015. (ASEAN, "History - The Founding of ASEAN", www.asean.org.asean.about-asean history; KMPG Asia Pacific Tax Centre, "The ASEAN Economic Community 2015 - On The Road to Real Business Impact" (2014, June), Retrieved from http://www.kmpg.com, p.3 at 13th January 2017; ASEAN IPR SME Helpdesk Guide, "Intellectual Property \& the ASEAN Economic Community (AEC) in 2015", Retrieved from http://www.southeastasia-iprhelpdesk.eu at 13th January 2017; Christopher W Runckel, "Asia Opportunities: Asean Economic Community (AEC) in 2015", business-in-asia.com, Retrieved from http: www.business-inasia.com/asia/asean_economic_community. html at 13th January 2017)

3 ASEAN, “A Blueprint for Growth ASEAN Economic Community 2015": Progress and Key Achievements, Retrieved from http://www.asean.org/storage/images/2015/November/aec-page/AEC-2015Progress-and-KeyAchievements.pdf

4 See the history of EC Josephine Steiner \& Lorna Woods, Textbook on EC Law, Oxford University Press, Oxford, 2003, p.1-7; To have better understanding of the history of Europe please read Paul Dukes, $A$ History of Europe 1648-1948: the Arrival, The Rise, The Fall, MAC Millan Publishers Ltd., London, 1985

5 EU Learning, Extension: What is Regional Integration?, Retrieved from http:www.carleton.ca/ces/ eulearning/ introduction/what-is-the-eu/extension-what-is-regional-integration/) at 13th January 2017

${ }^{6}$ AEC, Retrieved from http://www.asean.com at 13th January 2017; ASEAN IPR SME Helpdesk Guide, loc.cit. 
AEC Blueprint $2025^{7}$ which is designed to facilitate the achievement of a number of ASEAN's objectives. These objectives include: an ASEAN region that is cohesive and integrated; a regional economy that is competitive, innovative and dynamic; increased sectoral cooperation and connectivity; as well the development of human resources that are resilient, inclusive, people-oriented, and the development of people-centred communities that are integrated with the global economy. ${ }^{8}$

With those goals in mind, the AEC becomes especially strategic to ensure a regional economy that is competitive and that can also bring welfare to its people. This is a logical conclusion given ASEAN's great economic potential. With a total combined population of more than 600 million people, ASEAN's regional economic integration can help put ASEAN on the map, with a combined population that exceeds the US and even the EU. ${ }^{9}$ The AEC is also an important development to increase ASEAN's position amongst other powerful countries in the Asian region, such as China, India and Japan. ${ }^{10}$

Notwithstanding the excellent roadmap that was designed through the 2025 Blueprint, it will mean nothing if it is not supported by the full commitment and effort of the ASEAN Member States to realize the objectives. To achieve such objectives and to realize the roadmap, it is critical that the Member States adopt regulatory and policy reform in the field of economy, especially in trademark law and investment law. Considering that AEC's implementation is left to the discretion of each Member State, divergences of standard with respect to the Member State's trademark law and investment law will be inevitable without any serious harmonization efforts. This fact will create a legal issue with respect to the legal coherence of trademark law and investment law of the ASEAN Member States, or lack thereof.

\footnotetext{
${ }^{7}$ The AEC Blueprint 2025 was adopted by the leaders of the ASEAN Member States at the 27th ASEAN Summit on 22 November 2015 in Kuala Lumpur, Malaysia. That Summit produced numerous broad guidelines to guide ASEAN's strategic actions from 2016 to 2025. Together with the ASEAN Community Vision 2025 and the ASEAN Political-Security Community (APSC) Blueprint 2025 as well as the ASEAN Socio-Cultural Community (ASCC) Blueprint 2025, the ASEAN AEC Blueprint are all designed to achieve ASEAN 2025. (http://asean.org/asean-economic-community/).

8 "ASEAN Economic Community", http://asean.org/ asean-economic-community/

9 ADB, "ASEAN Economic Community: 12 Things to Know", http:www.adb.org.features.aseaneconomy-community-12-things-know; ASEAN IPR SME Helpdesk Guide, Loc. Cit.

${ }^{10}$ Christopher W Runckel, loc.cit.
} 


\section{Research Questions}

There are two main issues which will be focused in this paper: first, what are challenges for achieving legal coherence in trademark law and investment law in ASEAN countries? Second, what are principles and strategies for legal coherence in trademark law and investment law in ASEAN countries under AEC?

\section{Research Objectives}

The objectives of this paper are as follows: first, to examine challenges for achieving legal coherence in trademark law and investment law in ASEAN countries. Second, to analyze principles and strategies for legal coherence in trademark law and investment law in ASEAN Countries under AEC.

\section{Research Methods}

This research is a normative legal one which adopts library research by analyzing secondary data ${ }^{11}$, such as primary, secondary and tertiary legal materials/sources. In general, library reserach includes legislations and regulations, court decisions, official documents, related research reports, dictionary, encyclopedia, etc. ${ }^{12}$ However, for the purpose of this paper, it limits the sources on ASEAN level, particularly ASEAN Economic Community Blueprint 2025 (AEC Blueprint 2025), opinions from experts in law journals or books, and other related books and dictionaries. It applies two approaches; statute and comparative ones. Statute approach is an approach which focuses on legislations and regulations. ${ }^{13}$ Due to the scope of the topic, it focuses on AEC Blueprint 2025 as the guidance in discusing legal coherence in the ASEAN countries. Another approach, comparative approach is also used in this research based on the reason that ASEAN countries consists of those which have different legal systems, cultures and the development of economic and technology. All legal sources and other data obtained through the library research are separated and categorized based on the

11 Ronny Hanitidjo Soemitro, Metodologi Penelitian Hukum, Ghalia Indonesia, Semarang, 1982, p. 24; Maria SWS Sumardjono, Pedoman Pembuatan Usulan Penelitian, FH UGM, Yogyakarta, 1989, p. 16. This research is also called doctrinal (see E. Saefullah Wiradipradja, Penuntun Praktis Metode Penelitian dan Penulisan Karya Ilmiah Hukum, Keni Media, Bandung, 2015, p.25

${ }^{12}$ Maria SW Sumardjono, Ibid., p. 17-18; E. Saefullah Wiradipradja, Ibid., p.25-26.

13 Peter Mahmud Marzuki, Penelitian Hukum, Kencana, Jakarta, 2005, p.96-97 
research questions. The data is finally analyzed qualitatively by focusing on answering the research questions. ${ }^{14}$

\section{Research Result and Discussion}

\section{The Terminology of Legal Coherence}

The word 'Coherence' is defined in the Official Dictionary of the Indonesian Language as the integration of different fragments or points of view so that each of those parts can be connected to form a unified whole. ${ }^{15}$ Based on this definition, it is clear that the connectivity and consistency of regulations are a prerequisite of achieving legal coherence. Hence, legal coherence can be defined as a body of laws and regulation that is systematically integrated and is interconnected with one another.

\section{Overview of AEC Blueprint 2025}

As a regional economic cooperation, the AEC will have significant repercussions towards the development of trademark law and investment law in the ASEAN region. These ramifications stem from the five primary characteristics and elements of the AEC Blueprint 2025, namely: 1. A Highly Integrated and Cohesive Economy; 2. A Competitive, Innovative, and Dynamic ASEAN; 3. Enhanced Connectivity and Sectoral Cooperation; 4. A Resilient, Inclusive, PeopleOriented, and People-Centred ASEAN; and 5. A Global ASEAN.

These five characteristics become the core mission of the ASEAN countries to achieve through the Blueprint in order to develop an economic region that can equally compete with the big and influential players in world trade. In order to realize an economic region with such characteristics, each characteristic will be further elaborated as follows:

\section{A Highly Integrated and Cohesive Economy}

One important element of the AEC Blueprint 2025 is a highly integrated and cohesive economy. This element is vital because the achievement of a single integrated and cohesive market is the primary yardstick in measuring the success of a regional economic integration. This covers the following: a) trade in goods; b) trade in services; c) investment environment; d) financial integration,

\footnotetext{
14 See E. Saefullah Wiradipradja, Op. Cit., p.42.

${ }^{15}$ Kamus Besar Bahasa Indonesia Online, Retrieved from, http://kbbi.web.id at 13th January 2017
} 
financial inclusion and financial stability; e) skilled labour and business visitor; and $\mathrm{f}$ ) enhancing participation in global value chains. ${ }^{16}$

A Competitive, Innovative, and Dynamic ASEAN

The objective of this characteristic is to increase region's competitiveness and productivity by focusing on a) effective competition policy; b) Consumer Protection; c) Strengthening Intellectual Property Right Cooperation; d) Productivity-driven Growth, Innovation, R\&D and technology Commercialization; e) Taxation Cooperation; f) Good Governance; g) Regulation and Good Regulatory Practice; h) Sustainable Economic development; i) Global Megatrends and Emerging Trade -Related issues. ${ }^{17}$

Enhanced Connectivity and Sectoral Cooperation

The main objectives of this characteristic are to enhance economic connectivity involving various sectors, namely, transport, telecommunication and energy. In order to achieve the goal, this focuses on the following important elements: a) Transport; b) Information and Communication Technology; c) E-Commerce; d) Energy; e) Food, Agriculture and forestry; f) Tourism; g) Healthcare; h) Minerals; i) Science and technology. ${ }^{18}$

A Resilient, Inclusive, People-Oriented, and People-Centred ASEAN

This characteristic deals with the third characteristic of the AEC Blueprint 2015 on "Equitable Economic Development". Through this characteristic, The AEC Blueprint 2025 deepens existing elements and incorporating other key elements as follows: a) Strengthening the Role of Micro and SME; b) Strengthening the Role of Private sector; c) Public-Private Partnership; d) Narrowing the Development Gap; e) Contribution of Stakeholders on Regional integration efforts; and f) Enhanced Participation in Global Supply Networks. ${ }^{19}$

A Global ASEAN

The objectives of this characteristic is to continue to make steady progress towards integrating the region into the global economy through FTAs and comprehensive economic partnership agreements (CEPs) with China, Japan, Republic of Korea, India, Australia and New Zealand. Other agenda that is still ongoing is negotiations to conclude the Regional Comprehensive Economic Partnership (RCEP) and the ASEAN-Hong Kong FTA (AHKFTA). ${ }^{20}$

\section{Trademark Law and Investment Law in Asean Countries: A Brief Background}

\section{Trademark law}

The compliance of the ASEAN countries with the international standards of intellectual property protection has been started since the establishment of World Trade Organization (WTO) in 1994. One of the most important annexes under the

\footnotetext{
16 ASEAN, AEC Blueprint 2025, ASEAN Secretariat, Jakarta, 2015, p. 3-11.

${ }^{17}$ Ibid., p. $12-21$.

${ }^{18}$ Ibid., p. $21-30$

${ }^{19}$ Ibid., p. $30-35$

${ }^{20}$ Ibid., p. 35-36.
} 
administration of WTO is the Trade Related Aspects of Intellectual Property Rights (the TRIPS Agreement). The existence of the TRIPS Agreement brought new approaches in protecting intellectual property internationally in ASEAN. To follow up their commitment and to establish effective intellectual property protection, ASEAN has made several economic agreements. One of them is the ASEAN Framework Agreement on Intellectal Property Cooperation in late - 1995. ${ }^{21}$ Various IPR cooperation initiatives have also been made, such as : the Hanoi Plan of Action (HPA), ASEAN IPR Action Plans 2004 - 2010 and 2011-2015.22

Amongst other branches of intellectual property, trademark law constitutes an important topic to discuss due to its role in economy and international trade in ASEAN region. However, some issues dealing with the weak law enforcement against trademark infringement remain big problems in this region. Counterfeit products or imitated goods, different registrable signs, and international trademark registration system are the problems need to be harmonized in order to realize legal coherence in trademark law in ASEAN countries.

\section{Trademark counterfeiting}

The reputation of ASEAN as one of the popular markets for counterfeit products is notorious. ${ }^{23}$ This phenomenon is trigerred by the demand of ASEAN middle class which increases in number. To realize this, local business tends to use other well-known brands or trademarks from outside ASEAN as the guidance to develop their own products which potentially lead to imitation of branded products. ${ }^{24}$

\section{Various registrable signs}

Most ASEAN countries protect conventional trademarks, such as words, letters, numerals, pictures, color composition or combinations of one or more elements

${ }^{21}$ Marie Wilson, "TRIPS Agreement Implications for ASEAN Protection of Computer Technology" Annual Survey of International and Comparative Law, Vol. 4 (1997), p. 18-21; see Christopher Antons, "Intellectual Property Law in Southeast Asia: Recent Legislative and Institutional Developments", https://warwick.ac.uk/fac/soc/law/elj/jilt/2006_1/antons-removed/antons.pdf, p. 1-2; see also Nurul Barizah, “The Development Of Asean's Intellectual Property Rights Law; From Trips Compliance To Harmonization", Indonesia Law Review (2017) 1: 95 - 112, https://media.neliti.com/media/publications /62955-EN-thedevelopment-of-aseans-intellectual-p.pdf, p. 96; Elizabeth Siew-Kuan Ng, ASEAN IP Harmonization: Striking the Delicate Balance, 25 Pace Int'lL.Rev.129(2013),https://digitalcommons.pace.edu/cgi/viewcontent.cgi? referer=http:/ / digitalcommons.pace.edu/cgi/viewcontent.cgi?article=1330\&context $=$ pilr\&httpsredir=1\&article $=1330 \&$ context $=$ pilr, p. 137 .

${ }^{22}$ Elizabeth Siew-Kuan Ng, Ibid., p. 139.

${ }^{23}$ Peter N. Fowler, "Defining Notorious Markets: Physical and Online, Department of Commerce, US Patent and Trademark Office," https://www.iacc.org/Orlando\%20Conference\%20Dox/Presentations/ 02_Fowler.pdf, p. 2-7.

${ }^{24}$ IPR SME Helpdesk, "Guide to Trademark Protection In South East Asia”, http://www.southeastasiaiprhelpdesk.eu/sites/default/files/publications/EN_TM.pdf, p. 1 
in their domestic laws. Meanwhile non-conventional marks, such as shapes, holograms, and sounds, are only protected by few countries. ${ }^{25}$

\section{International Trademark Registration System}

The length of trademark registration process generally takes about 2 to 24 months. In ASEAN countries the process varies among the members. The process of trademark registration in Brunei, Indonesia, Malaysia, the Philippines, Thailand, and Vietnam is about 18-24 months. Other countries, such as Cambodia, Laos, and Singapore take 8 to 12 months and in Myanmar it takes 2 to 4 months. ${ }^{26}$ In terms of trademark registration system in ASEAN, Singapore, Malaysia and Brunei have similar system. Two countries, Cambodia and Philippines require filing of declarations of use and Myanmar has no registration system. ${ }^{27}$ This will be a potential problem in the future because an economic integration needs an integrated trademark registration system. In order to realize the legal coherence in this matter, ASEAN members need to comply with Madrid Protocol, one of the most important agreements in international trademark registration. Indonesia became the member of Madrid Protocol on 2 January 2018. This compliance makes Indonesia as the eighth member of ASEAN which joins the Madrid Union. ${ }^{28}$ Meanwhile other two countries, Malaysia and Myanmar are still in the process of joining the protocol. ${ }^{29}$ The role of Madrid Protocol is vital because if ASEAN members do not join the Madrid protocol, applicants or trademark owners need to register locally in those non-member countries. ${ }^{30}$ By ratifying this protocol, the member can seek protection of their trademarks in other member countries. ${ }^{31}$

\section{Investment Law}

Investment constitutes an important element of regional economic integration. ${ }^{32}$ As one of the most important tools in developing economy, the development of investment law is an interesting phenomenon in ASEAN. With diverse combination of its potentials ranging from structural capabilities and

${ }^{25}$ Ibid., p. $1-4$

${ }^{26}$ Tilleke \& Gibbins, "Protecting Your Brands and Trademarks in the Asean Economic Community", AsiaPacific January 22 2016, https://www.lexology.com/library/detail.aspx?g=79da0458-d4b0-4013-a012990c9060248f

27 Yew Woon Chooi, "How to Protect Marks and The Impact of ASEAN Countries Joining the Madrid Protocol on Trademark Strategies", IP Week (2015), 26 August 2015, http://www.managingip.com/pdfs/ IPSG15/Asiawidetrademarkspanel.pdf, p. 4

28 WIPO, “100 Members and Counting: Madrid System Welcomes Indonesia”, October 2 2017, http:www.wipo.int/madrid/en/news/2017/news_0020.html; Shilpi Saxena, Jr., "100 and counting: Indonesia joins Madrid Protocol", November 7, 2017, http://www.khuranaandkhurana.com/2017/11/07/100-andcounting-indonesia-joins-madrid-protocol/

${ }^{29}$ Alexander Bayntun-Lees, "South-East Asia IPR Basics Series: Trade Marks in Malaysia", 18-Mar-2016, http://www.youripinsider.eu/trade-marks-malaysia/; see Mirandah connecting Asia, Myanmar IP Services, https://www.mirandah.com/where-we-are/ myanmar/; see also Shilpi Saxena, Jr., Ibid.

${ }^{30}$ Yew Woon Chooi, Loc. Cit

31 Shilpi Saxena, Jr., Op. Cit.

32 Mariani Sallehuddin, "Critical Issues on Investment Law Harmonization within ASEAN", https://www.aseanlawassociation.org/11GAdocs/workshop3-brunei.pdf, p. 1 
natural resources to labor skills, ASEAN region attracts investors to participate in enhancing the ASEAN economy. ${ }^{33}$

To strengthen the regional integration through investment, leaders of ASEAN countries have launched several policies since the 1980s, such as Investment Guarantee Agreement or ASEAN IGA in 1987, the Framework Agreement on ASEAN Investment Area (AIA) in 1998 and followed by ASEAN Comprehensive Investment Agreement (ACIA) in 2007.34

In terms of regulations, investment laws in the ASEAN member have many differences. As the leading economy in the region, Singapore, in fact has no specific investment law. All investment matters in the country can be found in various laws and regulations, such as company law, contract law and other related laws. Similar approach is also followed by Brunei which relies on other laws, policies, and administrative practices to regulate investment. ${ }^{35}$ Malaysia has multiple investment laws which are governed by several laws. Meanwhile Philippines and Thailand have two different investment laws. Some other countries, such as Indonesia, Vietnam, Laos, Myanmar and Cambodia have a specific investment law. 36

Substantively, there are several reasons of choosing investment law as the example of legal coherence in ASEAN countries:

\section{Investment Law Has Different Function}

In the ASEAN region, the function of investment law varies from one to another. Some are intended to establish a process for the review and approval of new investment (such as Vietnam's new Law on Investment of 2014), and others are

33 Jones Day, "The ASEAN Economic Community: Investment Opportunities and Challenges in the World's Newest Market”, Commentary, February 2016, http://www.jonesday.com/files/Publication/ca71c5ab9c8d-4384-a8a9-a123fbb83943/Presentation/PublicationAttachment/e78899ed-dd35-4cf1-9f01-af35c0b78348/ ASEAN\%20Economic\%20Community\%20Commentary\%20A4.pdf , p. 2

34 Mariani Sallehuddin, Op. Cit., p. 1-6; see also Nguyen Tien Lap, "Critical Issues of Investment Harmonization Within ASEAN from Vietnam Perspective", ALA Workshop, Bali 14-19 February, 2012, https://www.aseanlawassociation.org/11GAdocs/workshop3-viet.pdf, p. 1

35 Jonathan Bonnitcha, "Investment Laws of ASEAN Countries: A Comparative Review", December 2017 https://www.iisd.org/sites/default/files/ publications /investment-laws-asean-countries.pdf, p, iii, 3.

36 The details of the Acts are as follows: Malaysia (Promotion of Investment Act of 1986, the Industrial Coordination Act of 1975, and the Environmental Quality Act of 1974), Philippines (Foreign Investment Act of 1991 and Omnibus Investment Code of 1987), Thailand (Foreign Business Act of 1999 and Investment Promotion Act of 1977), Indonesia (The Investment Law of 2007), Vietnam (Investment Law of 2014), Myanmar (Investment Law of 2016), Laos (Law on Investment Promotion of 2009), Cambodia (Investment Law of 2003) in Jonathan Bonnitcha, Ibid., p. 5 -24 
for the granting of investment incentives (examples are Malaysia's Promotion of Investment Act of 1986 and Thai Investment Promotion Act). ${ }^{37}$

Investment Dispute Resolution Is Not Regulated in the ASEAN Member States

All members of ASEAN have no specific articles in their investment laws to regulate the dispute settlement of investment between the investor and host government. However, the member allows arbitration as the method of dispute resolution under investor-state contract. ${ }^{38}$ It brings the consequence that those countries have their own way of managing the disputes. Actually, this problem can be easily solved by establishing a regional investment dispute settlement mechanism in ASEAN under ACIA. But, it is difficult to realize because it will conflict with ASEAN value of non-interference and national sovereignty. ${ }^{39}$ The alternative choice is to use the litigation in each member country. This method of resolution has also problematic because most ASEAN members (except Singapore) have been criticized by investors as the region which has challenges in recognizing, developing and enforcing the rights of investors due to rampant corruption, political cronyism and unpredictable legal regime. ${ }^{40}$

\section{Challenges For Achieving Legal Coherence}

Legal coherence in the field of trademark law and investment law must become a priority for all ASEAN Member States if ASEAN aims to reach the AEC's objectives. Unfortunately, however, those objectives may not be achieved if these critical factors are not adequately addressed:

\section{Diversity in Legal System}

ASEAN is composed of countries with a diverse range of legal systems. There are countries who adopt the common law system such as Malaysia, Singapore and Brunei Darussalam. Indonesia, on the other hand, adopts the civil law system. However, there are countries such as Thailand and the Philippines whose legal system draw on the features of both common law and civil law. ${ }^{41}$ Meanwhile, despite having roots in the civil law system, other countries such as Vietnam, Laos, Cambodia and Burma are still the process of finding their own identities for their legal system. ${ }^{42}$ This diversity in legal system will become one of the determining factors in making legal coherence in the field of trademark law. An example is the existence of passing-off in common law system. This

${ }^{37}$ Ibid., p. 1, 12, 21, and 23

38 Ibid., p. iii

${ }^{39}$ Jones Day, Op.Cit., p. 4

${ }^{40}$ Ibid., p. 4-5.

41 Deborah A. Hass. (1994). "Out of Others' Shadows: ASEAN Moves Toward Greater Regional Cooperation In the Face of the EC and NAFTA", 9:3 American University Journal of International and Policy 809, 814 at 857-863 In Joanne Wong, (2013, October 31) On Legal Harmonisation Within ASEAN, ,Singapore Law Review, Retrieved from http://www.singaporelawreview.org/2013/10/on-legal-harmonisation-within-asean/ at 04th November 2017

42 To understand the general differences between Common Law and Civil Law please read Nadia E. Nedzel, Legal Reasoning, Research, and Writing for International Graduate Students, Second Edition, Aspen Publishers, New York, 2008, p. 1-5 
protects unregistered trademarks which have a reputation or good will ${ }^{43}$ against infringement. But, passing-off is not recognized in civil law. Only Singapore, Malaysia, Brunei and Myanmar provide the protection of unregistered trademarks. ${ }^{44}$ In investment law, the different legal system can also be problem because all investment laws in ASEAN Countries do not regulate investment dispute settlement. These will be settled by arbitration or litigation in each country and create different mechanisms of investment dispute settlement amongst member states due to different legal systems.

\section{Economic and Technological Development Gap}

As is the case with their legal system, the ASEAN Member States also have varying economic and technological development. Although in terms of its population, Singapore can be classified as a relatively small country, it is at the forefront of economic and technological development in the ASEAN region. Bigger countries such as Indonesia, Thailand, Philippines and Malaysia subsequently follow in their economic and technological growth. However, other Member States are only starting to experience improvement in their economic and technological capacities. This can be a problem for legal coherence because different economic and technological level brings about the differences in development priority. In trademark law for example, some ASEAN countries (for example Indonesia and Singapore) protect non-conventional trademarks (holograms, shapes, sounds) but Myanmar has no specific trademark regime which protects explicitly such registrable signs as trademarks. ${ }^{45}$ In investment law, some investment laws of the member states function as investment incentives but others focus on another function, namely the review and approval of new investment. These differences are caused by different level of development priority where the source is from different level of economy and technology amongst Member States.

\section{Difference in Legal Culture}

Legal culture may be defined as the ideas, values, and collective behaviour and opinions of those who work in the legal profession specifically, or any other people generally, pertaining to the law and legal system that applies in their society. 46 The society's response to the values of their legal culture can be seen from the discipline and legal compliance of the people. In this regard, the most commonly highlighted aspect of legal culture is the enforcement of the law. Singapore with its rapid economic and technological development is among the best in ASEAN in terms of its law enforcement. This is evident from the behaviour of its citizens and government who demonstrates discipline and adherence to its stringent and consistent regulations. Meanwhile, the other Member States are still struggling to achieve a comparable level of such disciple

${ }^{43}$ IPR SME Helpdesk, Op. Cit., p.2

${ }^{44}$ Yew Woon Chooi, Loc. Cit.

${ }^{45}$ South - East Asia IPR SME Helpdesk, "Guide to Trade Mark Protection in South-East Asia" http://www.southeastasia-iprhelpdesk.eu/sites/default/files/publications/EN_TM.pdf, p. 2-4: see also the latest Indonesian Trademark Act No. 20 of 2016 on Trade mark and Geographical Indications , Article 1.1.

${ }^{46}$ US Legal, Definitons, Retrieved from http://definitions.uslegal.com/1/legal-culture at 04th November 
in their legal culture as exemplified by Singapore. The actions against trademark infringement are the best example to explain this fact. Singapore has one of the lowest rates in the world dealing with visible counterfeiting. This is because the enforcement is supported by updated and comprehensive Singaporean laws and courts which are tough on infringers. ${ }^{47}$ It is clear that law enforcement is part of legal culture which is among the most decisive factors to establish legal coherence in AEC.48

Disparity in the Level of Infrastructure Development

Infrastructure is highly strategic supporting factor in the realization of economic integration. Without adequate and modern infrastructure, it will be exceedingly difficult to ensure that the market can support a free and efficient trade in goods and services. Based on the report of the US International Trade Commission on the AEC, efficiency in conducting export and import is still one of the major barriers to the implementation of the AEC. Singapore, Thailand and Malaysia are considered to have an efficient trade procedure. However, the case is the contrary with respect to the trade procedures of Laos and Cambodia. If remain unaddressed, the disparity in trade procedure and infrastructure will be a significant impediment to the success of ASEAN's economic integration. ${ }^{49}$ The implementation of international trademark registration system, trademark protection, and the protection of investor capitals also depend on the availability of modern and sophisticated infrastructures.

The Principles and Strategy For Legal Coherence In Trademark Law and Investment Law

\section{Principles for Legal Coherence}

\section{Legal Harmonization}

Considering that ASEAN Member States face the aforementioned issues and challenges in implementing AEC, in principle, the efforts towards legal coherence should be undertaken as soon as possible without having to wait for those divergences to be overcome. In this regard, harmonizing the law could be considered as an alternative to achieving legal coherence in trademark law and investment law in the ASEAN region. Through legal harmonization, the Member States can agree to a number of objectives and targets, and each country can then subsequently amend their internal laws to achieve the agreed goals. ${ }^{50}$

\footnotetext{
47 Wong Siew Hong, "Singapore - World Trademark Review”, http://www.world trademarkreview.com/ Intelligence/Anti-Counterfeiting/2012/Country-chapters/Singapore, p. 117-119.

48 See Kho Shu Yan and Gregory Marimuthu, "Harmonising Intellectual Property Laws In Asean", http:/ /www.gateway-law.com/newsletter/Harmonization\%20and\%20IP.pdf, p. 2

${ }^{49}$ Christopher W Runckel, Loc. Cit.

50 Joanne Wong, Loc. Cit.
} 
The reason why harmonizing the law is the preferred method to address the current issues is because that method is realistic and can be implemented rapidly. Harmonization can be done by synchronising minimum standards that are general in nature and can be implemented by each Member States, irrespective of the legal system that is prevalent in that jurisdiction, the gap in economic and technological development, and the disparity in legal culture and infrastructure. ${ }^{51}$

Nonetheless, changes that are aimed towards increasing economic and technological innovation, as well as significant and gradual transformation of legal culture and infrastructure must be carried out by all Member States to support the effective implementation of AEC. To implement legal harmonization, however, ASEAN should remember that the nature of ASEAN itself is not the same as European Union which is categorized as a supranationality. Consequently, each member of ASEAN is free to implement legal harmonization according to their unique condition and local context.

Simon Pettman argued that there are a number of actions that must be taken by the ASEAN Member States to harmonize the standards in order to achieve the creation of a single market, among others: 1) standardizing the national policies and standards in order to prevent conflict with other standards at the regional level; and 2) harmonizing the technical regulations and convergence of safety standards for production in the ASEAN region. All those regulations also encompass mandatory technical regulations, such as registration and pre-market approval requirements. The effective harmonization of standards will enable the free movement of goods in the ASEAN region. 52

The Pettman's opinion on legal harmonization is very applicable in establishing legal coherence in trademark law. ASEAN members are working to realize international harmonization, such as shortening the examination processing

\footnotetext{
51 Wikipedia, "Harmonisation of Law", Retrieved from https://en.m.wikipedia.org/wiki/Harmonisation _of_law at 04 November 2017

52 Simon Pettman, "Standard Harmoniation In ASEAN; Progress, Challenges And Moving Beyond 2015", ERIA Discussion Paper Series, 2013 available at http://www.eria.org/publications/discussion_papers /standardsharmonisation-in-asean-progress-challenges-and-moving-beyond-2015.html; to understand the process of harmonization in ASEAN please compare the process of harmonization of internal community trade (in Jeremy M. Rosenberg, Dictionary of International Trade, John Wiley \& sons., Inc., New York, 1994, p. 155
} 
period. ${ }^{53}$ The implementation of ASEAN Common Form for trademark registration is an example of legal harmonization of trademark registration in the ASEAN region. ${ }^{54}$ The plan of establishing the ASEAN regional trademark and patent systems under the ASEAN Framework Agreement on Intellectual Property Cooperation is also example of legal harmonization without changing the substance of trademark laws in the ASEAN region. ${ }^{55}$ The most important progress in harmonizing trademark registration in ASEAN is the Common Guidelines for the Substantive Examination of Trademarks in ASEAN Countries. This Guidelines is part of cooperation between ASEAN and EU under the EU-ASEAN Project on The Protection of Intellectual Property Rights (ECAPS III). This is to support the objectives of AEC Blueprint and strategic goals identified in the ASEAN IPR Action Plan 2011-2015. The guidelines will be used to supplement the national manuals and guidelines of trademark examination in several IP offices in ASEAN. ${ }^{56}$

\section{Elimination of Barriers within the Borders, Beyond the Borders and Cross Borders}

The second principle relates to the scope of harmonization for trademark law and investment law in the ASEAN region. Romeo A. Reyes states that a single market cannot be achieved if the barriers at the following three locations are not eliminated: barriers at the borders, beyond the borders and cross borders. 57 Referring to Reyes' opinion above, the scope of the policies and regulations designed to achieve legal coherence in trademark law and investment law must always cover those three areas. Dealing with the protection of registered trademarks in the borders against the trademark infringement, the role of customs in ASEAN region is very important. One of possible actions is to seize the import

\footnotetext{
${ }^{53}$ Kho Shu Yan and Gregory Marimuthu, Loc. Cit.

54 WIPR, “ASEAN and Madrid: Six Down, Four to Go”, https://www.worldipreview.com/ contributedarticle/asean-and-madrid-six-down-four-to-go, 23 May 2017; see also ASEAN Common Form for trade mark, http://www.asean.org/uploads/archive/ipr_form.pdf

55 For more detail information about the ASEAN Framework Agreement on Intellectual Property Cooperation and the goal of establishing the ASEAN regional trademark and patent systems, please read Elizabeth Siew-Kuan Ng, op.cit, p.137-139.

${ }^{56}$ Common Guidelines For The Substantive Examination Of Trademarks, 2014, http://www.dgip.go.id/ images/ki-images/pdf-files/merek/asean-Guideline-full.pdf, p.4.

${ }^{57}$ Romeo A Reyes. (2004, November 30), "Forming Single Market: Theory and Reality", in ASEAN, ASEAN Economic Community, http: www.asean.org/communities/asean-economic-community at 04 November 2017
} 
of counterfeit product which enters the jurisdiction of each ASEAN country. Customs also have a task to inspect illicit goods which are in transit. 58

\section{Strategies for Legal Coherence}

In order to achieve an interconnected and coherent regulation for the trademark law and investment law of ASEAN countries, these strategies may be completed by Indonesia and the other Member States:

- All policies pertaining to the legal coherence of trademark law and investment law should refer to the ASEAN Economic Community Blueprint;

- The focus of legal harmonization must be directed towards the synchronisation of principles and standards that are general in nature through standardisation and the enactment of technical regulations as argued by Simon Pettman;59

- Each country should be advised to actively conduct legal harmonization ${ }^{60}$ of the AEC Blueprint;

- Legal coherence in trademark law and investment law that is not yet regulated under the Blueprint can be conducted by referring to the relevant international standards;

- Each effort for harmonization that will touch upon any aspects of trademark law and investment law must address the barriers at the borders, beyond the borders and cross borders ${ }^{61}$;

- The Ministerial Meetings should be prioritised for countries whose economic and technological development are relatively on-par and who have land borders with other Member States to ensure the free movement of goods, services, investment, labour and capital. An example of this would be: 1) Indonesia and Malaysia 2) Singapore and Malaysia 3) Malaysia and Thailand.

\section{Closure}

To conclude, the AEC has great potential to increase the economic growth and to empower the human potential of the ASEAN countries in the current era of free trade. Unfortunately, however, the AEC may also become a boomerang for the ASEAN Member States if the respective government and legislative bodies do not have a strong commitment to ensure the effective implementation of the economic integration. According to the discussion from the previous pages, it can be concluded that:

\footnotetext{
${ }^{58}$ Wong Siew Hong, Op.Cit., p.118

${ }^{59}$ Simon Pettman, Loc. Cit.

${ }^{60}$ As a comparison please read the meaning of harmonization in Leslie Rutherford and Sheila Bone, Osborn's Concise Law Dictionary, Osborn's Concise Law Dictionary, Eighth Edition, Sweet \& Maxwell, London, 1993, p. 163

61 See Rome o A. Reyes, Loc. Cit.
} 
1. legal coherence in the field of trademark law and investment law may be achieved if ASEAN members can manage some challenges, such as diversity in legal system, economic and technological development gap, difference in legal culture, disparity in the level of infrastructure development.

2. The principles of legal coherence are legal harmonization and elimination of barriers within the borders, beyond the borders and cross borders. Several strategies are also needed to achieve the legal coherence. These include focusing on the ASEAN Economic Community Blueprint as the guidance for legal coherence and applying legal harmonisation through standardisation and technical regulatory reform.

The experience of other countries which have gone through a similar economic integration, such as the EU, can also be a valuable reference to prepare for the legal harmonization. One of the countries that can be the focus of the comparative study is the Netherlands, as a country who adopts the civil law system. Furthermore, the United Kingdom may also become a cross-reference to see how the common law system accommodates such harmonization. Ultimately, these two countries have demonstrated their potent ability to adapt and adjust their national laws to ensure consistency with the EU laws, without having to fundamentally alter the legal system that has already existed in their jurisdiction.

In light of those research findings, the author would suggest the following points:

1. To optimise the benefit and positive effects that can be attained through the AEC, the government of the ASEAN Member States need to cooperate with the legislative bodies in each respective state to prioritise collecting the data of all regulations, especially in the subdivisions of trademark law and investment law, and to observe the growth and trends that are happening in the cooperation framework of other regional economies.

2. Regional and international cooperation must also be conducted to anticipate the harmonization of trademark law and investment law.

\section{Bibliography \\ Books}


Dukes, Paul, A History of Europe 1648-1948: the Arrival, The Rise, The Fall, MAC Millan Publishers Ltd., London, 1985.

Nedzel, Nadia E., Legal Reasoning, Research, and Writing for International Graduate Students, Second Edition, Aspen Publishers, New York, 2008.

Marzuki, Peter Mahmud, Penelitian Hukum, Kencana, Jakarta, 2005.

Jeremy M. Rosenberg, Dictionary of International Trade, John Wiley \& sons., Inc., New York, 1994.

Rutherford, Leslie and Sheila Bone (ed.), Osborn's Concise Law Dictionary, Eighth Edition, Osborn's Concise Law Dictionary, Sweet \& Maxwell, London, 1993.

Soemitro, Ronny Hanitidjo, Metodologi Penelitian Hukum, Ghalia Indonesia, Semarang, 1982.

Steiner, Josephine \& Lorna Woods, Textbook on EC Law, Oxford University Press, Oxford, 2003.

Sumardjono, Maria SWS, Pedoman Pembuatan Usulan Penelitian, FH UGM, Yogyakarta, 1989.

Wiradipradja, E. Saefullah, Penuntun Praktis Metode Penelitian dan Penulisan Karya Ilmiah Hukum, Keni Media, Bandung, 2015.

\section{Journals}

Antons, Christopher, "Intellectual Property Law in Southeast Asia: Recent Legislative and Institutional Developments", https://warwick.ac.uk/ fac/soc/law/elj/jilt/2006_1/ antons-removed/antons.pdf , at 10 March 2018

Barizah, Nurul, “The Development Of Asean's Intellectual Property Rights Law; From Trips Compliance To Harmonization", Indonesia Law Review (2017) 1: 95 - 112, https://media.neliti.com/media/publications/62955-EN-thedevelopment-of-aseans-intellectual-p.pdf, at 19 March 2018

Hass, Deborah A., "Out of Others' Shadows: ASEAN Moves Toward Greater Regional Cooperation In the Face of the EC and NAFTA", 9:3 The American University Journal Of International Law And Policy 809, 814 at 857-863, 1994

Siew-Kuan Ng, Elizabeth, "ASEAN IP Harmonization: Striking the Delicate Balance", 25 Pace Int'l L. Rev. 129 (2013), https: / /digitalcommons.pace.edu/cgi/viewcontent.cgi?referer=http:/ /di gitalcommons.pace.edu/cgi/viewcontent.cgi?article=1330\&context=pilr\& httpsredir=1\&article=1330\&context=pilr, at 23 March 2018

Wilson, Marie, “TRIPS Agreement Implications for ASEAN Protection of Computer Technology", Annual Survey of International and Comparative Law, Vol. 4 (1997)

Wong, Joanne, “On Legal Harmonisation Within ASEAN", Singapore Law Review, 2013, October 31 Retrieved from http://www.singaporelawreview. 
org/2013/10/on-legal-harmonisation-within-asean/ at 04th November 2017

\section{Internet}

ADB, "ASEAN Economic Community: 12 Things to Know", Retrieved from http:www.adb.org.features.asean-economy-community-12-things-know at 04 November 2017

AEC, Retrieved from http:/ / www.asean.com at 13th January 2017

ASEAN, "Medical Practitioners (AJCCM)", Retrieved from http:/ / asean.org/asean-economic-community/sectoral-bodies-underthe-purview-of-aem/services / healthcare-services/medical-practitionersajccm/ at 07th November 2017

ASEAN Economic Community, Retrieved from http:/ / asean.org/asean-economiccommunity / at 04 November 2017

ASEAN IPR SME Helpdesk Guide, 'Intellectual Property \& the ASEAN Economic Community (AEC) in 2015", Retrieved from http:/ /www.southeastasiaiprhelpdesk.eu at 13th January 2017

ASEAN, "The AEC Blueprint 2025", Retrieved from http://asean.org/aseaneconomic-community/ at 04 November 2017

ASEAN, "A Blueprint for Growth ASEAN Economic Community 2015:Progress and Key Achievements", Retrieved from http:/ / www.asean.org/storage/ images/2015/November/aec-page/AEC-2015-Progress-and-Key Achievements. pdf

ASEAN, "History - The Founding of ASEAN", www.asean.org.asean.about-asean history

Bayntun-Lees, Alexander, "South-East Asia IPR Basics Series: Trade Marks in Malaysia", 18-Mar-2016, http://www.youripinsider.eu/trade-marksmalaysia/, at 23 March 2018

Chooi, Yew Woon, "How to Protect Marks and The Impact of ASEAN Countries Joining the Madrid Protocol on Trademark Strategies", IP Week (2015), 26 August

2015,

http:/ / www.managingip.com/pdfs/IPSG15/Asiawidetrademark spanel.pdf, at 23 March 2018

"Common Guidelines For The Substantive Examination Of Trademarks", 2014, http://www.dgip.go.id/images/ki-images/pdf-files/merek/aseanGuideline-full .pdf, at 23 March 2018

“ASEAN Common Form for $\quad$ Trademark", http://www.asean.org/uploads/archive/ipr_form.pdf

EU Learning, “Extension: What is Regional Integration?", Retrieved from http:www.carleton.ca/ces/eulearning/introduction/what-is-theeu/extension -what-is-regional-integration at 13th January 2017 
Fowler, Peter N., "Defining Notorious Markets: Physical and Online”, Department of Commerce, US Patent and Trademark Office https://www.iacc .org/Orlando\%20Conference\%20Dox/Presentations/02_Fowler.pdf, at 23 March 2018

IPR SME Helpdesk, "Guide to Trademark Protection In South East Asia, http:/ / www.southeastasiaiprhelpdesk.eu/sites/default/files/publicatio ns/EN_TM. pdf, at 19 March 2018

Jones Day, Commentary, The ASEAN Economic Community: Investment Opportunities and Challenges in the World's Newest Market", February 2016, http://www.jonesday.com/files/Publication/ca71c5ab-9c8d-4384a8a9-a123fbb83943/Presentation/PublicationAttachment/e78899ed-dd354cf1-9f01af35c0b78348/ASEAN\%20Economic\%20Community\%20 Commentary\%20A4.pdf, at 14 March 2018

Kamus besar bahasa Indonesia Online, Retrieved from, http:/ / kbbi.web.id at 13th January 2017

KMPG Asia Pacific Tax Centre, "The ASEAN Economic Community 2015 - On The Road to Real Business Impact" (2014, June), Retrieved from http:/ / www.kmpg.com at 13th January 2017

Kho Shu Yan and Gregory Marimuthu, "Harmonising Intellectual Property Laws In Asean", http://www.gateway-law.com/newsletter/Harmonization\% 20and\%20 IP.pdf, at 23 March 2018

"Mirandah Connecting Asia", Myanmar IP Services, https://www.mirandah. com/where-we-are/ myanmar/, at 23 March 2018

Nguyen Tien Lap, "Critical Issues of Investment Harmonization Within ASEAN from Vietnam Perspective", ALA Workshop, Bali 14-19 February, 2012, https: / / www.aseanlawassociation.org/11GAdocs/workshop3-viet.pdf, at 19 March 2018

Pettman, Simon. (2013), "Standard Harmoniation In ASEAN; Progress, Challenges And Moving Beyond 2015", ERIA Discussion Paper Series, http://www.eria.org/publications/discussion_papers/standardsharmonisation-in-asean-progress-challenges-and-moving-beyond 2015.html, at 10 January 2018

Reyes, Romeo A. (2004, November 30), "Forming Single Market: Theory and Reality", in ASEAN, ASEAN Economic Community, http : www.asean.org/ communities/asean-economic-community at 04 November 2017

Runckel, Christopher W, “Asia Opportunities: ASEAN Economic Community (AEC) in 2015", business-in-asia.com, Retrieved from http: www.businessin-asia.com/asia/asean_economic_community. html at 13th January 2017

Saxena, Shilpi, Jr., "100 and Counting: Indonesia Joins Madrid Protocol", November 
2017,http://www.khuranaandkhurana.com/2017/11/07/100-andcounting-indonesia-joins-madrid-protocol/, at 23 March 2018

Sallehuddin, Mariani, "Critical Issues on Investment Law Harmonizing Within ASEAN", https://www.aseanlawassociation.org/11GAdocs/workshop3brunei.pdf, at 19 March 2018

Tilleke \& Gibbins, "Protecting Your Brands and Trademarks in the Asean Economic Community", Asia-Pacific January 22 2016, https://www.lexology.com/library/ detail.aspx?g=79da0458-d4b0-4013a012-990c9060248f, at 18 March 2018

US Legal, Definitons, Retrieved from http://definitions.uslegal.com/l/legalculture at 04th Novemver 2017

Wikipedia, "Harmonisation of Law”, Retrieved from https://en.m.wikipedia.org/ wiki/Harmonisation_of_law at 04 November 2017

WIPO, "100 Members and Counting: Madrid System Welcomes Indonesia", October 2

2017, http:www.wipo.int/madrid/en/news/2017/news_0020.html, at 23 March 2018

WIPR, "ASEAN and Madrid: Six Down, Four to Go", 23 may 2017, https://www.worldipreview.com/contributed-article/asean-andmadrid-six-down-four-to-go, at 23 March 2018 